\title{
On the Cost of Knowledge: Evaluating the Boycott against Elsevier
}

\author{
Tom Heyman*, Pieter Moors and Gert Storms \\ Department of Experimental Psychology, University of Leuven, Leuven, Belgium
}

Keywords: open access publishing, boycott, publication practices, social dilemmas, publication list

In the pre-Internet era, commercial publishers, such as Elsevier and Wiley, played an important role in disseminating new scientific ideas and discoveries. The emergence of the Internet has forced publishers to rethink their business model (Cope and Phillips, 2014), partly because scientists could, in principle, easily reach a broad audience and cut out the proverbial middleman. It is fair to say that commercial publishers adapted quite successfully as they arguably remain key players in the scientific publishing landscape (Cope and Kalantzis, 2014; Larivière et al., 2015). However, academics have been criticizing publishers' business practices for over a decade now [e.g., Dyer (2004)] and the call for reform has grown even louder in the past couple of years (Corbyn, 2012; Flood, 2012; Cope and Kalantzis, 2014). A prime example of such a reform initiative is the Cost of Knowledge campaign. Launched in response to a blog post by prominent mathematician Gowers (2012), the campaign specifically targets the publishing house Elsevier, denouncing its attempts to restrict the free exchange of information, the exorbitantly high prices for subscriptions, and the practice of selling journals in large bundles featuring many unwanted titles. ${ }^{1}$ Signatories of the

OPEN ACCESS

Edited by:

Xianwen Wang,

Dalian University of Technology,

China

Reviewed by:

Yishan Wu,

Chinese Academy of Science and Technology for Development, China

Ann Grand,

University of Western Australia, Australia

*Correspondence: Tom Heyman tom.heyman@kuleuven.be

Received: 17 August 2016 Accepted: 29 September 2016 Published: 17 October 2016

Citation:

Heyman T, Moors $P$ and Storms $G$ (2016) On the Cost of Knowledge: Evaluating the Boycott against Elsevier.

Front. Res. Metr. Anal. 1:7. doi: 10.3389/frma.2016.00007 petition pledge to not referee for, publish in, or do editorial work for Elsevier journals. Roughly 4 years after the boycott started, it seems appropriate to evaluate its impact and contemplate its future.

As a result of the boycott, several academics resigned from the editorial boards of numerous Elsevier journals. Moreover, the entire editorial board of the Elsevier journal Lingua resigned and started a new, open access journal called Glossa (Greenberg, 2015). The boycott thus changed the publishing landscape to a certain extent but not as drastically as the organizers might have hoped.

More importantly, however, over $80 \%$ of the nearly 16,000 signatories pledged to not publish in an Elsevier journal. This could gradually reduce the quality and thus the relevance of those journals. However, such a process takes time, and its effects may not be readily discernible. One might, therefore, wonder whether it provides much leverage in persuading Elsevier, or any other publisher for that matter, to change its policies. Moreover, one could question the feasibility of such a (long-term) commitment, especially the "won't publish" pledge. Given the seemingly ever-growing emphasis in academia on publishing papers in high impact journals, it might put a non-trivial burden on one's career. From previous studies, and perhaps personal experience, we know that good resolutions sometimes run aground (Norcross et al., 2002). But what about the "won't publish" commitment? Do signatories stick to their guns and indeed refrain from publishing in Elsevier journals? This is an interesting question because the success of such an initiative largely depends on the persistence of its signatories. Put differently, a petition such as the Cost of Knowledge can influence policy decisions to the extent that its signatories remain committed.

${ }^{1} \mathrm{http}: / /$ thecostofknowledge.com 
To get an idea about the success rate of the "won't publish" resolution, we checked signatories' publication history after they signed the petition. Using ResearchGate, Google Scholar, Academia.edu, LinkedIn, ScienceDirect, and lab or personal websites, we were able to compile a bibliography for a large sample of "won't publish" signatories. Due to the time-consuming nature of this research, we limited ourselves to two subject areas, Chemistry and Psychology, each with approximately 500 signatories.

It turns out that a substantial portion of the signatories was either unidentifiable (21\%) or had not published in any outlet, to our knowledge, since signing (19\%). However, 23\% of the signatories did publish in an Elsevier outlet after signing the petition. ${ }^{2}$ This number is somewhat higher in Chemistry (29\%) compared with Psychology (17\%). The remaining 37\%, indeed, published exclusively in non-Elsevier outlets. In other words, $38 \%$ of the publishing signatories abandoned their "won't publish in an Elsevier outlet" commitment [i.e., $23 \% /(23 \%+37 \%)$ ].

One needs to be cautious, however, not to overinterpret this potentially devastating number. First, not every author may be consulted on where to submit a manuscript. Even though all authors should in principle approve the manuscript including the targeted outlet, some may not have been as integrally involved in the research and, consequently, have little say in these matters. Indeed, a small number of "won't publish" signatories explicitly hedged their commitment, for instance, because they might not always choose the journal. Strictly speaking, one can refuse authorship in such cases, but various motivations may deter authors from taking this road (e.g., peer-pressure, the desire to be rewarded for the invested effort, etc.). To address this issue, signatories' author positions were taken into account. In many fields, including Psychology and Chemistry, the first and last author positions are considered to be the most prestigious. These are typically reserved for the lead investigator and the supervisor or department head, respectively. Hence, it is often the case that the first and/or last author decides where to publish a manuscript. The data show that signatories are often "merely" co-authors (i.e., 46\% in Psychology, 65\% in Chemistry), yet they do occupy an influential position in many instances (i.e., only author: $2 \%$ in Psychology, 1\% in Chemistry; first author: 26\% in Psychology, $12 \%$ in Chemistry; last author: $26 \%$ in Psychology, 22\% in Chemistry).

Furthermore, there are a number of other reasons why signatories might have decided to publish in an Elsevier journal after all. Sometimes, there may be confusion about the publisher. For instance, Cell Press was originally an independent publisher with titles such as Cell and Neuron, but it later became part of the Elsevier group. Consequently, these titles do not look like the typical Elsevier journal, which may have misled some signatories. In addition, most Elsevier journals now have a paid open access option and some are even completely open access

${ }^{2}$ Most (recent) Elsevier publications have an article history detailing when an article was received by the journal. These dates (when available) were used to derive whether signatories published in an Elsevier outlet since signing. Note that conference abstracts and proceedings were not considered as publications. (e.g., Sleep Science). It is fair to wonder whether such open access articles, especially the latter type, represent an abandonment of the "won't publish in an Elsevier outlet" commitment.

Taking these nuances into account, the earlier conclusion that $38 \%$ of the publishing signatories broke their "won't publish" promise, seems too pessimistic. However, it is also important to keep in mind that the present data concern a relatively short time span of maximally 4 years. One might thus wonder what the number would be in, say, 10 years' time. Furthermore, this search is limited to manuscripts that were eventually accepted for publication. The actual number of manuscripts submitted to an Elsevier journal, including those that were rejected or are currently under review, is arguably considerably higher. Finally, the publication history of some articles lacked the essential information to determine whether the author(s) signed the petition before or after submitting the manuscript. In such cases, we gave signatories the benefit of the doubt even though it was often fairly obvious that they abandoned their commitment.

So, what is the take-home message? It is hard to live up to the "won't publish" commitment, just like any other resolution. The entire situation actually resembles a social dilemma in which people might reason: "If I still publish in impactful Elsevier journals and most other researchers/signatories stop publishing in these journals, it will be good for my résumé/career, while Elsevier will have to change its ways." From this point of view, the boycott's moderate "success rate" is not surprising. That said, the Cost of Knowledge petition partly misses its goal if, after only 4 years, $38 \%$ of the publishing signatories have in fact published in an Elsevier journal since signing. A petition can only influence policy making if its signatories are unified and remain committed to the cause in question. Furthermore, only $37 \%$ of the "won't publish" signatories are clearly boycotting Elsevier by publishing elsewhere. Extrapolating this figure to other domains would altogether amount to about 5,000 researchers - a drop in the ocean when we consider the total number of (publishing) scientists in the world. ${ }^{3}$ Barring a surge in (media) attention to the boycott, it seems unlikely that this number will grow substantially. Indeed, relatively few researchers have signed the petition in recent years, thus giving the impression that the boycott has run its course. That is to say, the negative publicity surrounding the boycott initially did elicit some (half-)measures from Elsevier (e.g., withdrawing support for the Research Work Act, a bill intended to restrict open access to research; Elsevier, 2012). However, any further changes resulting from the boycott as such seem utopian, unless other organizations join the cause. Put differently, efforts like these may require "high-level" support from universities and/or funding bodies to truly have an impact. For example, the Association of Universities in the Netherlands (VSNU) launched a boycott against Elsevier last year, which involved asking journal editors to resign (Kingsley, 2015). Soon after, they were able to reach an agreement with Elsevier about

\footnotetext{
${ }^{3}$ Note that the vast majority of signatories work(ed) in Western Europe or North America, whereas signatories from developing countries are scarce.
} 
gradually granting open access to articles written by Dutch scientists (VSNU and Elsevier, 2015), though the agreement itself has already drawn criticism (Hartgerink, 2016). This does not mean that individual researchers can only stand by and watch, though. Everyone can, for instance, help create a culture of transparency by uploading pre- and/or postprints to one's personal website or repositories such as arXiv. The effects may be modest (initially), but this "resolution" is easily attainable and ensures open access to (publicly funded) research [see Björk et al. (2014) for a review of this so-called green open access route].

Taken together, the Cost of Knowledge petition is a noble initiative that fits into a broad movement to make research accessible and transparent. Yet, it might consider moving forward with only those who genuinely rally behind the call to boycott Elsevier, and even then, it remains highly questionable whether Elsevier will significantly change its ways.

\section{REFERENCES}

Björk, B. C., Laakso, M., Welling, P., and Paetau, P. (2014). Anatomy of green open access. J. Assoc. Inf. Sci. Technol. 65, 237-250. doi:10.1002/asi.22963

Cope, B., and Kalantzis, M. (2014). "Changing knowledge ecologies and the transformation of the scholarly journal," in The Future of the Academic Journal, eds B. Cope and A. Phillips (Oxford: Chandos Publishing), 9-83.

Cope, B., and Phillips, A. (2014). The Future of the Academic Journal. Oxford: Chandos Publishing.

Corbyn, Z. (2012). White House petitioned to make research free to access. Nature News. Available at: http://www.nature.com/news/white-housepetitioned-to-make-research-free-to-access-1.10723

Dyer, O. (2004). US universities threaten to cancel subscriptions to Elsevier journals. BMJ 328, 543. doi:10.1136/bmj.328.7439.543

Elsevier. (2012). Elsevier Withdraws Support for the Research Works Act [Press release]. Available at: https://www.elsevier.com/about/company-information/ policies/message-on-the-research-works-act

Flood, A. (2012). Scientists sign petition to boycott academic publisher Elsevier. The Guardian. Available at: https://www.theguardian.com/science/2012/ feb/02/academics-boycott-publisher-elsevier

Gowers, T. (2012). Elsevier - My Part in its Downfall [Blog post]. Available at: https:/gowers.wordpress.com/2012/01/21/elsevier-my-part-in-its-downfall/

Greenberg, J. (2015). Editors of the journal Lingua protest - quit in battle for open access. Wired. Available at: http://www.wired.com/2015/11/ editors-of-the-journal-lingua-protest-quit-in-battle-for-open-access/

\section{AUTHOR CONTRIBUTIONS}

All the three authors developed the study concept. TH performed the literature search and conducted the analyses. TH drafted the manuscript, and PM and GS provided critical revisions.

\section{ACKNOWLEDGMENTS}

Signatories' names, affiliations, and the domain in which they work(ed) are available at http://thecostofknowledge.com. Timestamps were kindly provided by Tyler Neylon, creator of the Cost of Knowledge website. Timestamps for the earliest signatories were unavailable, so they were given the same liberal timestamp, meaning that they actually signed up before this date. We also thank Tim Gowers for his feedback. TH and PM are research fellows of the Research Foundation Flanders (FWO-Vlaanderen).

Hartgerink, C. H. J. (2016). VSNU Failed Itself in Meagre Deal With Elsevier [Blog post]. Available at: https://universonline.nl/2016/04/28/ vsnu-failed-itself-in-meagre-deal-with-elsevier

Kingsley, D. (2015). Dutch Boycott of Elsevier - A Game Changer? [Blog post]. Available at: https://unlockingresearch.blog.lib.cam.ac.uk/?p=192

Larivière, V., Haustein, S., and Mongeon, P. (2015). The oligopoly of academic publishers in the digital era. PLOS ONE 10:e0127502. doi:10.1371/journal. pone. 0127502

Norcross, J. C., Mrykalo, M. S., and Blagys, M. D. (2002). Auld Lang Syne: success predictors, change processes, and self-reported outcomes of New Year's resolvers and nonresolvers. J. Clin. Psychol. 58, 397-405. doi:10.1002/jclp.1151

VSNU and Elsevier. (2015). Dutch Universities and Elsevier Reach Agreement in Principle on Open Access and Subscription. Available at: https://www. elsevier.com/about/press-releases/corporate/dutch-universities-and-elsevier-reach-agreement-in-principle-on-open-access-and-subscription

Conflict of Interest Statement: The authors declare that the research was conducted in the absence of any commercial or financial relationships that could be construed as a potential conflict of interest.

Copyright (c) 2016 Heyman, Moors and Storms. This is an open-access article distributed under the terms of the Creative Commons Attribution License (CC BY). The use, distribution or reproduction in other forums is permitted, provided the original author(s) or licensor are credited and that the original publication in this journal is cited, in accordance with accepted academic practice. No use, distribution or reproduction is permitted which does not comply with these terms. 